\title{
An Analysis of Coetzee 's Animal Imagery and Ecological View
}

\author{
Ma Lei \\ Xi'an Institute of Translation, Xi'an, China, 710105
}

\begin{abstract}
Keywords: Coetzee; animal imagery; ecological view
Abstract. This paper analyzes the image of the marginalized other animals in Coetzee's works by analyzing the images of animals commonly found in Coetzee's works, combined with ecological criticism and ecological feminism, and interprets Coetzee's ecological ethics and morality view.
\end{abstract}

\section{Introduction}

John Coetzee, a South African writer and winner of the Nobel Prize for Literature in 2003, is said that he can use "perfect techniques and his own vocabulary to make his poetic ideas an integral part of western literature." and he is also one of the most commented contemporary writers. Since the 1990s, in the field of Coetzee's studies, the diversity of cultural identity, post-colonialism, cultural hegemony, diaspora writing, marginal writing, ecological criticism and so on are all able to find its surface, reflecting the openness and polysemy of Coetzee's research. The rich connotations, profound meanings and solemn language of the works lead the researchers to explore from various perspectives. In the same year, more researchers and scholars will pay their attention to Coetzee, mainly from the angle of post-colonialism, culture and society, clash of civilizations, feminism to elucidate his works.

As a writer with great social responsibility, Coetzee began to explore the relationship between man and nature, man and animal in his first novel The Underworld. In 1980, Waiting for the Barbarians touched the destruction for animals. In the Michael K's Life and Times", a harmonious relationship between main character and nature has been established, and people often get a sense of identity with animals. The change in the relationship between Lurie and the animal in Disgrace parallels his moral and spiritual identity. Eventually, his animal anxieties was further demonstrated in the prose Life of the Animals, with the help of Costello's interrogation and questioning against atrocities from human beings to animals. Elizabeth Costello: Eight Lessons once again questioned, "Are we the same with other animals have the same thing - ration, self-consciousness, soul?" Milan Kundera in the Life can not Afford Light said that "The true test of human nature is how to deal with the animals that need his compassion." In Coetzee's writings, animals are not only objects that require us to be concerned, but the other's status is also a mapping of the marginalized human condition. The sense of identity of animals is human beings in their own position in nature thinking and understanding. This paper begins with the common image of animals in Coetzee's works, analyzes the marginalized images of other animals in Coetzee's works, and interprets Coetzee's ecological ethics and morality.

\section{The other image of the animal}

Right to Animals is the first time that Coetzee calls for animal rights in the form of speeches. In his works, he uses the mouth of Elizabeth to regard mankind as a criminal, in order to satisfy his greed and ambition. "Here, hundreds and thousands of penguins are killed by sticks, and then thrown into the cast-iron pan, boiled, and become a useful oil and useless residue. Or, they are not killed by the rods, but by groups of people who are caught in a stick with a pedal and, at the end of the pedal, fall into the boiling hot pot. "(Coetzee: 67) In his novels, the human behavior of arbitrary killing of animals is everywhere. In Waiting for the Barbarians, a large-scale hunting by the chief executive of an imperial frontier led to "hundreds of deer, pigs and bears were killed and carcasses and dead bodies could not be recovered. (Coetzee: 1) and in Shame, Professor Lurie wanted to forbid the instinctive physiological responses of their male dogs when they see the bitches, as long as one saw the bitch and showed its desire and was beaten, and finally, the poor dog had a disgusted sense of their own nature, 
so that "a smell of bitch, the drooping ears, sandwiched tail, rushing around the yard, hum hum. (Coetzee: 101) Animal welfareists argue that animal welfare consists of five basic elements, namely, physical well-being, i.e, anxiety without hunger and thirst; environmental welfare, which is to allow animals to have welfare; sanitary welfare, which is to reduce the animal's injury; behavioral welfare, which should ensure that animal freedom of expression; psychological welfare, that is, to reduce animal fear and anxiety of the mood, but the fact is that human beings in order to meet their own desires can do whatever they want, on the nature and instinct of animals can be arbitrarily killed. Thus, the concern of animals as Coetzee's works in an important undercurrent, everywhere, passing the author's sympathy and appeal.

Animals in the end have no equal rights compared to human beings, and if they really have the same human soul, reason and wisdom? Darwin, in his theory of evolution, points out that humans and animals share a common ancestor, that humans evolved from animals, and that their relationship is a sibling, and that, by way of example, human beings and all other life forms have a certain species of universal genetic relationship. "As with other organisms, humans are members of the Earth's life community," says Paul W. Taylor, founder of the famous bioethicist and biocentricist theory. "Humans and other species are built together into an interdependent system, the survival and welfare of each species depends not only on the profit and loss of the physical environment, but also depends on his relationship with other organisms, all biological life is the purpose of life as the center of living, so each creature is independent." Since the animal and human solidarity, sharing the biosphere, then the human self is superior to the animal, is blasphemy, a despotic, and the only individual in their own advantage. Human is not inherently superior to other creatures. As the Rights of Animals says: "Our business is endless, self-renewing, and able to bring rabbits, mice, poultry and animals to this world with the aim of killing them." (96)

Whether through Elizabeth's accusation of Rights of Animals, or through the portrayal of the animal's atrocities in the novel, Coetzee is trying to subvert anthropocentrism, to awaken humans from false self-superiority, to face up to this animal and plant ecosystem, otherwise, the future we may face will be Waiting for the Barbarians as described in: "muddy dust cover the roof covered by overwhelming everywhere in the exposed. (204) In recent years, global warming, melting glaciers, sea-level rise, changes in rainfall patterns, overexploitation of the oceans, desert expansion, lack of freshwater resources, species loss, and the loss of freshwater resources accelerated extinction, so a variety of phenomena is already clear to us the trample on the consequences of nature.

\section{The View of Animal Rights from the Perspective of Transcendent Others}

As a diaspora writer, Coetzee's transcendental perspective shifted from "South Africa to the world, from the individual to the whole, from mankind to all animals, including humans." (Wang Jinghui: 21) Animal imagery is full in Coetzee's works, and they are intellectual, spiritual and emotional, but are also representatives of vulnerable groups and objects that need to be defended. In his writings, Coetzee criticized the relentless hunt of animals as a "rational" ethnic group, arguing that it was as barbaric as the slaughter of mankind. Colonel Joel talked about how he had killed thousands of deer, pigs and bears to fill the dead bodies of the barbarians in the beginning of Waiting for the Barbarians. Colonel Joel even ordered people to burn the bushes near river banks, the results of the fire through the reeds, poplars, like a torch burned up. Expanded animals such as antelope, hare, wildcat or something, all flew quickly; groups of birds flew in horror; Everything was burned. "(112) The brutal behavior of Colonel Joel, the empire's representative, contrasted sharply with the care of the old chief executive, who told the barbaric woman," The people will say that I have two wild animals, a fox, and a girl. "(51) This attitude reflects his principle of equality of animals and people. In the Shame, Lurie's the transformation of understanding of animal and the morality can be the formation of a double line, from the initial theory that the animal's soul is imperfect and animal animism, to the last dog euthanasia with the final for fear of cremation will hastily deal with the dog's body, he would put them home with a truck overnight, the next day sent to the cremation, and each time he drove home, halfway had to stop at roadside. Lucy and Beverly Shaw's attitude toward the dog deconstructed 
anthropocentrism from practical action. When Lurie persuaded her daughter to leave the farm, she was rebutted to " There is no higher level of life at all. Life is as it is now, and it is our shared life with animals. That's the example of a man trying to make a case like Beverly, and that's what I'm trying to learn. And animals share some privileges of human. "(83) If the novel through animal images reflects the animal rights of anxiety, the Animal Life is to borrow the mouth of Elizabeth Costello, with a philosophical dialectic expression of human indiscriminate killing animals, animal cruelty to anger. "Because it can not be proved, all animals do not have consciousness. What does this 'therefore' mean? So we can freely use them for our purposes? So we can kill them at will? Why? What is so special about the form of consciousness that it is a crime to kill a conscious person and to kill an animal without punishment? " $(55,56)$ and Elizabeth's identity as a vegetarian from the outset is the most potent accusation of killing animals. Animals have a soul, a conscious presence, we are animals, or just rational animals only. In Coetzee's works, animals are not only objects that need us to pay attention to. Other animals' status is also the mapping of the marginalized human condition. The recognition of animals is the reflection and cognition of mankind's status in nature. Seeing the animal soul, Coetzee also saw the connection between women and animals, and saw the link between the ravages of animals and nature as well as the oppression of women under patriarchy.

\section{The ecological feminism thought reflected by animal imagery}

"Only when human rights are truly respected and the rights of animals can be realized" (Wang Jinghui: 285) In the works of Coetzee, both animals and women are insulted and damaged, and their natural connection with nature determines the contact with animals in their works. "The conquest of mankind and the conquest between man and man are two villains in a pair of trousers, each with a different appearance," says Weil Plumer. "(14) As for Wait for the Barbarians, in the eyes of the old chief executive, the savage woman was the same animal as the fox. When he first tried to influence her in a condescending gesture, though she could use her body, she could not enter her mind and soul. Only in the barbaric way with appreciation of the equal view can he achieve a real combination, really fall in love with her and get her love. In the Shame, Professor Lurie harassment of prostitutes and female students is the same with his initial attitude to animals, that is, they are the objects can be used also are silent and passive. In a male-dominated society like South Africa, women, like the colonized race, have no self, especially in South Africa. "In the minds of white men, there is an internal resemblance between women and colonial peoples, He (she) who is on the edge or the subordinate position and is considered as alien to the other by white men. (Luogang, Liu Xiangyu: 5) Professor Lurie only in the farm after her daughter's rape, after getting the salvation of thought and soul from Lucy and Beverly, can he learn to respect the animal life and human dignity. In the culture of patriarchal society, "animal - female - nature" is a unity, which are marginalized and alienated, and become victims.

Eco-feminist criticism is a kind of cultural thought which adapts to the needs of social change from the convergence of environmental movement and feminism movement. It takes care, love, friendship, honesty and reciprocity as its core values, providing a new critique for literary critics. Ecofeminism recognizes the natural connection between women and nature, and this link is stubbornly inherited through culture, language, and history. Ecological females mainly combine the oppression of animals with the women's liberation movement, because human beings can get salvation only in the women, only in the process of loving animals and nature. The quite popular contemporary green feminism describes women as " Eco-system angel " with women love, feeding, good cooperation, close to others and nature. (Plumed: 11) The role of women in the works of Coetzee is precisely this mission. In Shame, Lucy after being raped, not like the father hated blacks or chose to call the police, while she even in the black boy peeping her bath and hurt by the dog, helped for his bandaged wounds, or even chose to marry the black worker, with a kind of atonement of love and tolerance to integrate into the African land. Professor Lurie began to despise what Beverly Shaw has done and persuaded her to choose a higher level of life, but in the end he realized: "Now, from the veterinarian (Beverly shaw), he learned to focus his attention on the dogs they killed (euthanized), on the word, which is that he no 
longer has the difficult term of love. "(219). Russell once wrote in The History of Western Philosophy: "Universal love is the driving force behind everything that I want in this world." (Russell: 326) In the natural ecosystem everything is interconnected and interdependent. Ecological feminism combines ecological ideas with feminism, opposes all forms of oppression and discrimination, and advocates the re-construction of new moral standards, social structure, and a society full of love and justice. Harmonious society should contain three levels of harmony: harmony between man and nature, harmony between man and man and their harmony. Loving people, loving animals and loving nature, is the ideal society from Coetzee.

From ancient times to the present, in the natural ecosystem, mankind is not the master, but depends on nature to exist and circulate. Awe should be the only attitude of man in nature. Albert Schweitzer's "reverence for life" of ethical view is that the scope of human ethics should be extended to all animals and plants, not just the relationship between people and that "thinking people must experience as awe his life will be the same fear of all life will, in his own life experience to experience other life. "There are many animal images in Coetzee works. The complaints for the murder of animal, sympathy and love for animals are reflected in the the protection of animal rights, the pursuit of pluralistic life ethics, which he transcends the narrow interpersonal ethics, from the ecological holistic view of nature to look at and treat all things, to break the inherent anthropocentrism, and to appeal to human have humane care, perception and love towards animals.

\section{Fund Project}

Xi'an Institute of Translation 2015 annual scientific research key project (item number: 15A04)

\section{References}

[1] Coetzee. Animals Rights, North Tower Translation, Zhejiang Literature and Art Publishing, 2004

[2] Coetzee. Shame, Zhang Chong, Guo Zhengfeng translation, Nanjing: Yilin Publishing House, 2003

[3] Coetzee. Wait for the Barbarians, Wen Min Translated. Hangzhou: Zhejiang Publishing House, 2004

[4] Russell. The History of Western Philosophy (volume). Beijing: The Commercial Press, 1976

[5] Luo Gang, Liu Xiangyu. Post-colonialist Cultural Theory. China Social Sciences Press, 1999.

[6] Wang Nuo. Ecological Criticism and Ecological Thinking. Beijing: People's Publishing House, 2013 